\title{
PENGARUH PERTUMBUHAN EKONOMI, JUMLAH ANGKATAN KERJA, DAN TINGKAT UPAH TERHADAP PENYERAPAN TENAGA KERJA PROVINSI BALI
}

\author{
Ni Komang Pande Wiasih ${ }^{1}$ Ni Luh Karmini ${ }^{2}$
}

Article history:

Submitted: 26 Juni 2021

Revised: 15 Juli 2021

Accepted: 31 Juli 2021

\section{Keywords:}

Labor Absorption;

Economic Growth;

Number of Workforce,

Wages Level;

\section{Kata Kunci:}

Penyerapan Tenaga Kerja; Pertumbuhan Ekonomi; Jumlah Angkatan Kerja; Tingkat Upah;

\section{Corresponding:}

Fakulas Ekonomi dan Bisnis Universitas Udayana, Bali, Indonesia

Email:

pandewiasih400@gmail.com
The condition of labor absorption shows that the higher the unemployment rate, the higher the poverty, crime, and socio-economic phenomena in society. Absorption of labor is one of the supporters of economic developmentcarried out by developing countries and has the aim, among others, to create equitable economic development. This study aims: 1) To determine the effect of economic growth, the number of the workforce, and the wage level simultaneously on the absorption of district/city workers in the Province of Bali; 2) To determine the effect of economic grow th, the number of labor force, and the partial wagelevel on the absorption of labor in districts/cities in Bali Province. The data used is secondary data from 2010-2019 with quantitative and qualitative data types, then the data is processed using multiple linear regression analysis techniques. The results of this study indicate that: 1) Economic growth, the number of labor force, and the level of wages simultaneouslyaffect the absorption of labor; 2) Partially, economic growth has noeffect on employment. The number of laborforce and the wage level partially have a positive and significant effect on labor absorption.

\section{Abstrak}

Kondisi penyerapan tenaga kerja menunjukan bahwa semakin tin ggi angka pengangguran maka a kan meningkatkan kemiskinan, krim in a litas, dan fenomena-fenomena sosial-ekonomi di masyarakat. Penyerapantenaga kerja merupakan salah satu pendukung pembangunan ekonomi yang dilakukan oleh negara-negara berkembang dan mempunyai tu juan antara lain untuk menciptakan pembangunan ekonomi secara merata. Penelitian ini bertujuan: 1) Untuk mengetahui pengaruh pertumbuhan ek onomi, ju mlah angkatan kerja, dan tingkat upah secara simultan terha dap p en yera pan tena ga kerja kabupaten/kota di Provinsi Ba li; 2) Untuk mengetahui penganuh pertumbuhan ekonomi, jumlah angkatan kerja, dan tingkat u pah secara parsialterhadap penyerapan tenaga kerja kabupaten/kota di Provin si B ali. Da ta yang digunakan a dalah data sekunder dari ta hun 2010 - 2019 dengan jenis data kuantitatif dan kualitatif, kemudian data diolah teknik analisis regresi linier berganda. Hasil penelitian ini menunjukkan bahwa: 1) Pertumbuhan ekonomi, jumlah angkatan kerja, dan tin gkat u pah secara simultan berpengaruh terhadap penyerapan tenaga kerja; 2) Pertu mbuhan ekonomi secara parsial tidak berpengaruh terhadap penyerapan tenaga keja. Jumlah a ngkatan kerja dan tingkat upah secara parsial berpengaruh p o sit if dan signifikan terhadap penyerapan tenaga kerja.

Fakultas Ekonomi dan Bisnis Universitas Udayana, Bali, Indonesia ${ }^{2}$ Email:karmini@unud.ac.id ${ }^{2}$ 


\section{PENDAHULUAN}

Arsyad (2004) mendefinisikan pembangunan ekonomi sebagai proses peningkatan pendapatan rill perkapita penduduk dalam jangka Panjang yang disertai adanya perbaikan system kelembagaan. Pembangunan ekonomi bertujuan untuk meningkatkan taraf hidup dan kesejahteraan masyarakat. Indonesia memiliki ketersediaan sumber daya manusia yang potensial, namun permasalahan timbul karena terkendala pada bidang ketenagakerjaan yaitu lapangan pekerjaan yang tidak seimbang dengan tingginya jumlah penduduk. Perekonomian dapat dikatakan stabil apabila tingkat pengangguran kurang dari 4 (empat) persen dari jumlah pencari kerja (Sri Budhi, 2008). Kuncoro (2002) mengemukakan pengertian penyerapan tenaga kerja sebagai jumlah lapangan kerja yang terisi yang dicerminkan dari jumlah penduduk bekerja. Penduduk bekerja terserap karena adanya permintaan tenaga kerja, makadari itu penyerapan tenaga kerja bisa dikatakan pula sebagai permintaan tenaga kerja. Penyerapan tenaga kerja dapat dipengaruhi oleh beberapa faktor, yaitu tingkat upah, nilai produksi, struktur perekonomian, modal, produktivitas, dan TPAK.

Nasution (2015) menyebutkan bahwa ketidakseimbangan tingkat angkatan kerja dengan ketersediaan lapangan kerja dapat menyebabkan terjadinya pengangguran meningkat. Makadari itu pemerintah terus berupaya untuk menurunkan kemiskinan berdasarkan kebijakan terkait dan tidak mengintegrasi. Sebenarnya, ketika terjadi peningkatan jumlah penduduk diimbangi dengan peningkatan lapangan pekerjaan maka akan dapat mempercepat pembangunan daerah, karena penduduk adalah roda penggerak pembangunan (Ashcroft, 2008).

Provinsi Bali merupakan salah satu daerah yang mudah untuk dijangkau yang menyebabkan migrasi dan urbanisasi tidak dapat dielakkan. Situasi ini dapat mempengaruhi ketenagakerjaan dimana dapat menyebabkan membludaknya penduduk usia produktif (Arief \& Heny, 2015). Berdasarkan informasi yang diperoleh dari BPS Provinsi Bali mengenai jumlah penduduk usia kerja pada tahun 2010-2019 diketahui bahwa jumlah penduduk yang bekerja tertinggi pada tahun 2018 yakni sebesar 2.490.870 jiwa dengan TPAK 76,78\%, dan di tahun 2013 sampai tahun 2016 mengalami kenaikkan tetapi pada tahun 2019 menurun sebesar 2.428.679 jiwa. Kondisi ketenagakerjaan di Bali termasuk cukup baik, hal ini dapat dilihat pada tingkat pengangguran sebesar 1,37 persen, paling rendah dibanding daerah lainnya di Indonesia. Kendati demikian, masih ditemui permasalahan ketenagakerjaan selain tingkat pengangguran, seperti jumlah angkatan kerja, upah, kualitas dan persebaran tenaga kerja yang belum merata menyebar hingga wilayah terpencil di Bali.

Beberapa faktor yang mempengaruhi penyerapan tenaga kerja yang akan dianalisis yaitu pertumbuhan ekonomi, jumlah angkatan kerja, dan tingkat upah. Menurut Schumpeter dalam (Boediono, 2012:48) pertumbuhan ekonomi didefinisikan sebagai peningkatan output masyarakat karena bertambahnya faktor produksi yang digunakan dalam proses produksi tanpa mengubah cara teknologi itu sendiri. Dayuh (2012) menyebutkan bahwa pertumbuhan ekonomi memiliki hubungan erat dengan produksi, dimana semakin banyak barang dan jasa yag diproduksi akan turut meningkatkan pertumbuhan ekonomi. Amri (dalam Alghofari, 2009) mengemukakan bahwa pertumbuhan ekonomi suatu negara atau wilayah yang meningkat menggambarkan kondisi ekonomi di negaraa atau wilayah tersebut berkembang dengan baik. Apabila terus meningkat, maka aktivitas ekonomi juga akan bertambah sehingga akan turut meningkatkan permintaan tenaga kerja. Pertumbuhan ekonomi memberikan kesempatan kepada pemenrintah dalam memenuhi kebutuhan dasar masyarakatnya (Askenazy, 2003).

Pengaruh Perumbuhan Ekonomi, Jumlah Angkatan Kerja, dan Tingkat Upah Terhadap Penyerapan Tenaga 
Angkatan kerja didefinisikan sebagai penduduk usia kerja yang bekerja, yang memiliki pekerjaan tetapi sedang tidak bekerja untuk sementara, dan yang sedang mencari kerja. Penduduk yang bekerja adalah mereka yang aktif dalam kegiatan menghasilkan barang atau jasa atau mereka yang selama seminggu sebelum pencacahan melakukan pekerjaan atau bekerja dengan maksud memperoleh penghasilan selama paling sedikit 1 jam dalam seminggu yang lalu dan tidak boleh terputus. Sedangkan pencari kerja adalah bagian dari angkatan kerja yang sekarang ini tidak bekerja dan sedang aktif mencari pekerjaan (Subri, 2003). Angkatan kerja terbagi dalam kelompok penduduk yang bekerja dan pengangguran. Meningkatnya jumlah angkatan kerja yang tidak diimbangi oleh perluasan lapangan kerja akan membawa beban tersendiri bagi perekonomian yang akan berdampak pada penyerapan tenaga kerja.

Permasalahan ketenagakerjaa mendasar yang terjadi di Indonesia, khususnya Bali yaitu tingkat upah. Menurut Mankiw, N.G. (2000), upah merupakan salah satu faktor yang mempengaruhi tingkat pengangguran, karena naiknya upah minimum akan mengurangi permintaan tenaga kerja yang akan menimbulkan pengangguran. Neumark (2007) menyebutkan tingkat upah sebagai faktor pendukung dalam penyerapan tenaga kerja. Semakin tinggi tingkat upah yang ditetapkan pemerintah akan mempengaruhi jumlah orang yang bekerja (Alghofari, 2009).

Hasil penelitian yang dilakukan oleh Azaini (2014) menyatakan bahwa pertumbuhan ekonomi berpengaruh positif dan signifikan terhadap penyerapan tenaga kerja. Peningkatan pertumbuhan ekonomi adalah upaya untuk mengatasi permasalahan tenaga kerja yang belum dapat terserap secara maksimal. Dalam penelitian Eka Fitri (2019) diperoleh hasil bahwa variabel angkatan kerja berpengaruh positif dan signifikan terhadap penyerapan tenaga kerja pada seluruh Provinsi di Indonesia. Semakin tinggi jumlah angkatan kerja maka akan diikuti dengan peningkatan penyerapan tenaga kerja. Hasil penelitian Vivi (2016) menyatakan bahwa upah memiliki pengaruh positif terhadap penyerapan tenaga kerja. Upah sangat berpengaruh terhadap kesempatan kerja. Bertambahnya nilai upah bisa menyebabkan meningkatkan kehidupan layak seorang pekerja.

Berdasarkan rumusan masalah dan pembahasan hasil penelitian terlebih dahulu maka diajukan hipotesis sebagai berikut: H1: Pertumbuhan ekonomi, jumlah angkatan kerja, dan tingkat upah secara simultan berpengaruh terhadap jumlah penyerapan tenaga kerja Kabupaten/Kota di Provinsi Bali. H2: Pertumbuhan ekonomi, jumlah angkatan kerja, dan tingkat upah secara parsial berpengaruh positif terhadap jumlah penyerapan tenaga kerja di Kabupaten/Kota di Provinsi Bali.

\section{METODE PENELITIAN}

Penelitian ini merupakan penelitian kuantiatif yang bersifat asosiatif yang bertujuan untuk mengetahui hubungan dari beberapa variabel yaitu pertumbuhan ekonomi, jumlah angkatan kerja, dan tingkat upah terhadap penyerapan tenaga kerja Kabupaten/Kota Provinsi Bali. Penelitian ini dilaksanakan di Kabupaten/Kota Provinsi Bali yang mencakup semua Kabupaten/Kota di Provinsi Bali, karena dari data kondisi ketengakerjaan di Provinsi Bali dari tahun 2010-2019 yang diperoleh masih menunjukkan keadaan yang berfluktuasi pada penyerapan tenaga kerja. Obyek dalam penelitian adalah beberapa variabel yang berpengaruh terhadap penyerapan tenaga kerja antar Kabupaten/Kota Provinsi Bali tahun 2010-2019 seperti pertumbuhan ekonomi, jumlah angkatan kerja, dan tingkat upah. Data kuantitatif yang digunakan dalam penelitian ini adalah data mengenai pertumbuhan ekonomi, jumlah angkatan kerja, tingkat upah dan data penyerapan tenaga kerja Kabupaten/Kota

Pengaruh Perumbuhan Ekonomi, Jumlah Angkatan Kerja, dan Tingkat Upah Terhadap Penyerapan Tenaga 
Provinsi Bali tahun 2010-2019. Data kualititatif dalam penelitian ini adalah berupa penjelasan keteranga-keterangan yang berbentuk kata, kalimat, skema, dan gambaran variabel yang diteliti yaitu, mengenai gambaran umum situasi ketenagakerjaan wilayah Bali dan upaya - upaya pemerintah dalam mengatasi penyerapan tenaga kerja yang belum merata. Sumber data penelitian yaitu data sekunder yang diperoleh dari Badan Pusat Statistika Provinsi Bali dan literatur - literatur lain yang mendukung tentang objek penelitian ini. Jumlah pengamatan dalam penelitian ini adalah sebanyak 90 pengamatan. Metode pengumpulan data yang digunakan dalam penelitian ini adalah observasi non perilaku, yaitu teknik pengumpulan data yang dilakukan dengan cara mengumpulkan data dan melakukan pencatatan. Teknik analisis data yang digunakan dalam penelitian ini adalah metode regresi linier berganda, yang dapat dinyatakan dalam persamaan sebagai berikut:

$$
\mathrm{Y}=\alpha+\beta_{1} \mathrm{X}_{1}+\beta_{2} \mathrm{X}_{2}+\beta_{3} \mathrm{X}_{3}+\mu
$$

Keterangan:

$\mathrm{Y} \quad=$ Variabel terikat yaitu, tingkat penyerapan tenaga kerja

$\mathrm{X}_{1}, \mathrm{X}_{2}, \mathrm{X}_{3} \quad=$ Variabel Independen Pertumbuhan ekonomi, Jumlah angkatan kerja, Tingkat upah

$\beta_{1} \beta_{2} \beta_{3} \quad=$ Koefisien regresi masing-masing variabel independen

$\alpha \quad=$ Konstanta

$\mu \quad=$ Variabel pengganggu

\section{HASIL DAN PEMBAHASAN}

Berdasarkan Tabel 1 perkembangan laju pertumbuhan ekonomi menurut Kabupaten/Kota Provinsi Bali pada tahun 2010-2019 yang mengalami fluktuasi setiap tahuhnya.

Tabel 1.

Laju Pertumbuhan Ekonomi Menurut Kabupaten/Kota Provinsi Bali Tahun 2010 - 2019 (Persentase)

\begin{tabular}{lclllllllll}
\hline Kabupaten/ & \multicolumn{10}{c}{ Pertumbuhan Ekonomi } \\
\cline { 2 - 24 } & $\mathbf{2 0 1 0}$ & $\mathbf{2 0 1 1}$ & $\mathbf{2 0 1 2}$ & $\mathbf{2 0 1 3}$ & $\mathbf{2 0 1 4}$ & $\mathbf{2 0 1 5}$ & $\mathbf{2 0 1 6}$ & $\mathbf{2 0 1 7}$ & $\mathbf{2 0 1 8}$ & $\mathbf{2 0 1 9}$ \\
\hline Jembrana & 4.56 & 5.89 & 6.11 & 5.69 & 6.05 & 6.19 & 5.96 & 5.28 & 5.59 & 5.56 \\
Tabanan & 5.67 & 6.11 & 6.12 & 6.45 & 6.53 & 6.19 & 6.14 & 5.37 & 5.73 & 5.06 \\
Badung & 6.47 & 7.07 & 7.64 & 6.82 & 6.98 & 6.24 & 6.81 & 6.08 & 6.74 & 5.83 \\
Gianyar & 6.04 & 7.15 & 7.08 & 6.82 & 6.8 & 6.03 & 6.31 & 5.46 & 6.03 & 5.64 \\
Klungkung & 5.42 & 6.11 & 6.25 & 6.05 & 5.98 & 6.11 & 6.28 & 5.32 & 5.05 & 5.44 \\
Bangli & 4.97 & 6.14 & 6.02 & 5.94 & 5.83 & 6.16 & 6.24 & 5.31 & 5.05 & 5.47 \\
Karangasem & 5.09 & 5.43 & 5.93 & 6.16 & 6.01 & 6.00 & 5.92 & 5.06 & 5.48 & 5.5 \\
Buleleng & 5.85 & 6.44 & 6.78 & 7.15 & 6.96 & 6.07 & 6.02 & 5.38 & 5.62 & 5.55 \\
Denpasar & 6.57 & 7.16 & 7.51 & 6.96 & 7.00 & 6.14 & 6.51 & 6.05 & 6.43 & 5.84 \\
Provinsi Bali & 5.74 & 6.66 & 6.96 & 6.69 & 6.73 & 6.03 & 6.33 & 5.56 & 6.33 & 5.63 \\
\hline
\end{tabular}

Sumber: Badan Pusat Statitistik Provinsi Bali,2021

Berdasarkan Tabel 1 perkembangan laju pertumbuhan ekonomi menurut Kabupaten/Kota Provinsi Bali pada tahun 2010-2019 yang mengalami fluktuasi setiap tahuhnya. Laju pertumbuhan ekonomi paling tinggi tiap tahunnya ditunjukkan oleh Kabupaten Badung yaitu pada tahun 2012

Pengaruh Perumbuhan Ekonomi, Jumlah Angkatan Kerja, dan Tingkat Upah Terhadap Penyerapan Tenaga 
sebesar 7,64 persen namun pada tahun 2019 mengalami penurunan yaitu sebesar 5,83 persen. Kabupaten Jembrana memiliki laju pertumbuhan ekonomi paling rendah di Provinsi Bali, yaitu pada tahun 2010 sebesar 4,56 persen dan mengalami peningkatan pada tahun 2019 yaitu sebesar 5,56 persen.

Tabel 2.

Penduduk Angkatan Kerja Menurut Kabupaten/Kota Provinsi Bali Tahun 2010 - 2019 (Orang)

\begin{tabular}{|c|c|c|c|c|c|c|c|c|c|c|}
\hline \multirow{2}{*}{$\begin{array}{l}\text { Kabupaten/ } \\
\text { Kota }\end{array}$} & \multicolumn{10}{|c|}{ Angkatan Kerja } \\
\hline & 2010 & 2011 & 2012 & 2013 & 2014 & 2015 & 2016 & 2017 & 2018 & 2019 \\
\hline Jembrana & 141.489 & 152.237 & 155.121 & 140.474 & 146.400 & 144.733 & 155.065 & 163.765 & 165.193 & 145.505 \\
\hline Tabanan & 248.702 & 251.059 & 267.193 & 264.157 & 268.033 & 268.754 & 260.455 & 251.253 & 278.317 & 274.263 \\
\hline Badung & 314.087 & 309.897 & 325.375 & 327.647 & 324.471 & 339.966 & 344.522 & 344.882 & 365.988 & 383.662 \\
\hline Gianyar & 274.563 & 263.566 & 271.654 & 268.400 & 269.646 & 289.356 & 297.248 & 303.470 & 315.742 & 308.450 \\
\hline Klungkung & 106.146 & 95.002 & 98.586 & 101.530 & 102.801 & 105.601 & 106.025 & 104.956 & 108.538 & 106.993 \\
\hline Bangli & 133.547 & 140.332 & 143.068 & 141.205 & 144.833 & 138.082 & 140.503 & 143.245 & 149.640 & 146.585 \\
\hline Karangasem & 231.469 & 238.689 & 242.095 & 245.603 & 245.496 & 247.289 & 245.037 & 240.474 & 259.007 & 256.257 \\
\hline Buleleng & 343.638 & 343.346 & 359.779 & 353.000 & 342.975 & 352.510 & 361.049 & 366.940 & 382.591 & 350.778 \\
\hline Denpasar & 452.508 & 430.746 & 437.834 & 441.880 & 472.103 & 485.724 & 499.426 & 515.465 & 536.502 & 535.801 \\
\hline Bali & 2.246 .149 & 2.224 .874 & 2.300 .705 & 2.283 .896 & 2.316 .758 & 2.372 .015 & 2.463 .039 & 2.434 .450 & 2.561 .518 & 2.508 .294 \\
\hline
\end{tabular}

Sumber: Survei Angkatan Kerja Na sional (Sakernas) - Agustus, 2021

Berdasarkan Tabel 2 perkembangan jumlah penduduk angkatan kerja menurut Kabupaten/Kota Provinsi Bali mengalami fluktuasi setiap tahunnya. Dapat dilihat bahwa jumlah angkatan kerja di Provinsi Bali mengalami fluktuasi, dimana tahun 2010 jumlah angkatan kerja sebesar 2.246.149 orang menurun pada tahun 2011 sebesar 2.224.874 orang kemudian mengalami peningkatan pada tahun 2012 menjadi sebesar 2.300 .705 orang. Pada tahun 2013 mengalami penurunan sebesar 2.283 .896 orang, dan pada tahun 2014 sampai 2016 terus mengalami peningkatan hingga mencapai jumlah 2.463 .039 orang. Pada tahun 2017 kembali menurun sebesar 2.434 .450 orang dan meningkat pada tahun 2018 sebesar 2.561 .518 orang, pada tahun 2019 menurun lagi menjadi sebesar 2.508.294 orang.

Tabel 3.

Tingkat Upah Minimum Menurut Kabupaten/Kota Provinsi Bali 2010 - 2020 (dalam rupiah)

\begin{tabular}{|c|c|c|c|c|c|c|c|c|c|c|}
\hline \multirow{2}{*}{$\begin{array}{l}\text { Kabupaten/ } \\
\text { Kota }\end{array}$} & \multicolumn{10}{|c|}{ Upah Minimum } \\
\hline & 2010 & 2011 & 2012 & 2013 & 2014 & 2015 & 2016 & 2017 & 2018 & 2019 \\
\hline Jembrana & 875.000 & 927.500 & 1.000 .000 & 1.212500 & 1.542 .600 & 1.662500 & 1.834558 & 2.006 .617 & 2.181393 & 2.356 .559 \\
\hline Badung & 1.110 .000 & 1.221 .000 & 1.290 .000 & 1.401 .000 & 1.728 .000 & 1.905 .000 & 2.124 .075 & 2.299311 & 2.499581 & 2.700 .297 \\
\hline Gianyar & 925.000 & 1.003 .625 & 1.104 .000 & 1.230 .000 & 1.543 .000 & 1.707 .750 & 1.904 .141 & 2.061233 & 2.240 .766 & 2.421 .000 \\
\hline Karangasem & 875.000 & 953.750 & 1.039 .000 & 1.195 .000 & 1.542 .600 & 1.700 .000 & 1.895500 & 2.051 .879 & 2.180 .000 & 2.355 .054 \\
\hline Buleleng & 830.000 & 895.000 & 975.000 & 1.200 .000 & 1.542 .600 & 1.650 .000 & 1.839 .750 & 1.991529 & 2.165 .000 & 2.338 .850 \\
\hline Denpasar & 1.100 .000 & 1.191500 & 1.259 .000 & 1.358 .000 & 1.656 .900 & 1.800 .000 & 2.007 .000 & 2.173 .000 & 2.363 .000 & 2.553 .000 \\
\hline Bali & 829.316 & 890.000 & 967.500 & 1.181 .000 & 1.542 .600 & 1.621 .172 & 1.807 .600 & 1.956 .727 & 2.127 .157 & 2.297 .969 \\
\hline
\end{tabular}

Sumber: Dinas Tenaga Kerja dan Energi Sumber Da ya Mineral Provinsi Bali, 2021

Pengaruh Perumbuhan Ekonomi, Jumlah Angkatan Kerja, dan Tingkat Upah Terhadap Penyerapan Tenaga Provinsi Bali, 
Berdasarkan pada Tabel 3 perkembangan tingkat besaran upah minimum di Kabupaten/Kota Provinsi Bali. Dapat dilihat terjadi kenaikan upah mminimum pada setiap tahunnya untuk setiap Kabupaten/Kota Provinsi Bali 2010-2019. Dalam tabel tersebut dapat dilihat besaran upah minimum tertinggi pada tahun 2019 yaitu Kabupaten Badung sebesar 2.700.297rupiah dan posisi tertinggi kedua yaitu Kota Denpasar sebesar 2.553.000rupiah dibanding wilayah lainnya di Provinsi Bali, dan upah minimum yang terendah pada tahun 2019 yaitu pada Kabupaten Bangli pada tahun sebesar 2.299.152 rupiah.

Tabel 4.

Penduduk Yang Bekerja Menurut Kabupaten/Kota Provinsi Bali Tahun 2010 - 2019 (persen)

\begin{tabular}{lllllllllll}
\hline Kabupaten/ & \multicolumn{10}{c}{ Penduduk Yang Bekerja } \\
\cline { 2 - 11 } Kota & $\mathbf{2 0 1 0}$ & $\mathbf{2 0 1 1}$ & $\mathbf{2 0 1 2}$ & $\mathbf{2 0 1 3}$ & $\mathbf{2 0 1 4}$ & $\mathbf{2 0 1 5}$ & $\mathbf{2 0 1 6}$ & $\mathbf{2 0 1 7}$ & $\mathbf{2 0 1 8}$ & $\mathbf{2 0 1 9}$ \\
\hline Jembrana & 97,45 & 96,47 & 97,99 & 96,53 & 97,05 & 98,41 & 98,37 & 99,32 & 98,59 & 98,55 \\
Tabanan & 98,93 & 97,20 & 97,82 & 99,20 & 97,75 & 98,27 & 98,07 & 98,20 & 98,55 & 98,71 \\
Badung & 98,74 & 97,71 & 98,32 & 99,19 & 99,51 & 99,66 & 98,98 & 99,54 & 99,54 & 99,59 \\
Gianyar & 97,64 & 97,88 & 98,19 & 97,76 & 98,56 & 82,52 & 98,25 & 98,97 & 98,38 & 98,53 \\
Klungkung & 96,41 & 97,65 & 97,91 & 97,91 & 98,05 & 98,60 & 98,13 & 99,06 & 98,52 & 98,43 \\
Bangli & 99,35 & 99,19 & 99,10 & 99,23 & 99,32 & 98,28 & 99,02 & 99,52 & 99,18 & 99,24 \\
Karangasem & 97,18 & 97,29 & 98,69 & 98,61 & 97,94 & 97,85 & 98,09 & 99,27 & 98,97 & 99,37 \\
Buleleng & 96,73 & 96,72 & 96,86 & 97,85 & 97,26 & 97,96 & 97,41 & 97,59 & 98,11 & 96,87 \\
Denpasar & 93,43 & 95,44 & 97,43 & 97,27 & 97,67 & 96,45 & 97,15 & 97,37 & 98,13 & 97,70 \\
Bali & 96,93 & 97,04 & 97,90 & 98,16 & 98,09 & 98,00 & 98,11 & 98,51 & 98,60 & 98,43 \\
\hline Sunyyyyyyyyy
\end{tabular}

Sumber: Survei Angkatan Kerja Nasional(Sa kernas) - Agustus, 2021

Berdasarkan Tabel 4 perkembangan penduduk yang bekerja menurut Kabupaten/Kota Provinsi Bali. Dapat dilihat bahwa, kondisi ketenagakerjaan yang ada di Provinsi Bali menurut Kabupaten/Kota mengalami fluktuasi. Dimana pada tahun 2010 penduduk yang bekerja sebanyak 96,93 persen pada tahun 2011 hingga 2013 mengalami peningkatan menjadi sebanyak 98,16 persen. Pada tahun 2014 dan 2015 menurun menjadi sebanyak 98,00 persen. Tahun 2016 hingga 2018 meningkat sebanyak 98,60 persen dan pada tahun 2019 menurunan menjadi 98,43 persen.

Tabel 5

Hasil Statistik Deskriptif Variabel Penelitian

\begin{tabular}{lrrrrr}
\hline & N & Minimum & Maximum & \multicolumn{1}{c}{ Mean } & \multicolumn{1}{c}{ Std. Deviation } \\
\hline Pertumbuhan Ekonomi (X1) & 90 & 4.56 & 7.64 & 6.0537 & .61819 \\
Angkatan Kerja (X2) & 90 & 95002 & 536502 & 262866.54 & 115006.367 \\
Tingkat Upah (X3) & 90 & 829500 & 2700297 & 1614401.83 & 527459.148 \\
Penyerapan Tenaga Kerja (Y) & 90 & 82.52 & 99.66 & 97.9517 & 1.93526 \\
Valid N (listwise) & 90 & & & & \\
\hline
\end{tabular}

Sumber: Data Penelitian, 2021

Berdasarkan hasil uji statistik dapat diketahui bahwa jumlah data yang digunakan dalam penelitian ini sebanyak 90 data. Hasil statistik deskriptif masing-masing dalam penelitian ini dapat dijelaskan sebagai berikut:

Pengaruh Perumbuhan Ekonomi, Jumlah Angkatan Kerja, dan Tingkat Upah Terhadap Penyerapan Tenaga 
Variabel pertumbuhan ekonomi memiliki nilai minimum sebesar 4,56 persen yaitu menunjukkan persentase pertumbuhan ekonomi terendah terdapat pada Kabupaten Jembrana pada tahun 2010. Nilai maksimum sebesar 7,64 persen yaitu menunjukkan persentase pertumbuhan ekonomi tertinggi terdapat pada Kabupaten Badung pada tahun 2012. Variabel pertumbuhan ekonomi memiliki nilai rata-rata sebesar 6,0537 persen. Variabel jumlah angkatan kerja memiliki nilai minimum sebesar 95.002 orang yaitu menunjukkan jumlah angkatan kerja terendah terdapat pada Kabupaten Klungkung pada tahun 2011. Nilai maksimum sebesar 536.502 orang yaitu menunjukkan jumlah angkatan kerja tertinggi terdapat pada Kota Denpasar pada tahun 2018. Variabel jumlah angkatan kerja memiliki nilai rata-rata sebesar 262.866 .54 orang.Variabel tingkat upah memiliki nilai minimum sebesar 829.500rupiah yaitu menunjukkan tingkat upah terendah terdapat pada Kabupaten Banglipada tahun 2010. Nilai maksimum sebesar 2.700.297rupiah yaitu menunjukkan tingkat upah tertinggi terdapat pada Kabupaten Badung pada tahun 2019. Variabel tingkat upah memiliki nilai ratarata sebesar 1.614.401,83 rupiah. Variabel penyerapan tenaga kerja memiliki nilai minimum sebesar 82.52 persen yang menunjukkan jumlah penduduk yang bekerja terendah terdapat pada Kabupaten Gianyar pada tahun 2015. Nilai maksimum sebesar 99.66 persen yang menunjukkan jumlah penduduk yang bekerja tertinggi terdapat pada Kabupaten Badung pada tahun 2015. Variabel penyerapan tenaga kerja memiliki nilai rata-rata sebesar 97.9517 persen.

Berdasarkan perhitungan analisis regresi linear berganda, maka didapatkan hasil persamaan regresi sebagai berikut.

$\begin{array}{lcccc}\mathrm{Y}= & -96,000+0,260 \mathrm{X} 1+4,730006 \mathrm{X} 2+1,005006 \mathrm{X} 3+\mu \\ \mathrm{SE} & (2,500) & (0,397) & (0,000) & (0,000) \\ \mathrm{t} & -38,400 & 0,655 & 2,250 & 2,357 \\ R^{2}=0,328 & & & \\ \text { df }=89 & \end{array}$

Uji normalitas bertujuan untuk mengetahui apakah residual dari model regresi yang dibuat berdistribusi normal atau tidak. Pengujian normalitas data dilakukan dengan uji Kolmogorov-Smirnov. Berdasarkan hasil analisis, diperoleh hasil uji normalitas sebesar 0,869 dengan tingkat signifikan pada Asymp. Sig. (2-tailed) sebesar 0,437 lebih besar dari nilai alpha 0,05 yang menyatakan bahwa data sudah berdistribusi normal atau lulus dari uji normalitas. Uji multikolinearitas bertujuan untuk menguji pada model regresi ditemukan adanya korelasi antar variabel bebas atau tidak. Model regresi yang baik seharusnya tidak terjadi korelasi antar variabel bebas, yang dideteksi dari nilai torelence dan nilai VIF. Hasil pengujian diperoleh memiliki nilai tolerance $>0,10$ serta nilai VIF $<10$, sehingga dapat disimpulkan bahwa model persamaan regresi lolos uji multikolinearitas. Uji autokorelasi dalam penelitian ini menggunakan uji Durbin Watson (DW). Berdasarkan hasil pengujian diperoleh nilai DW 1,886 nilai ini bila dibandingkan dengan nilai tabel signifikan 5\% dengan jumlah sampel 90 (n) dan jumlah variabel independen $(K=3)$ maka diperoleh nilai du 1,7264. Nilai DW 1,886 lebih besar dari batas atas (du) yakni 1,7264 dan kurang dari (4-du) 4 - 1,7264 =2,2736, maka dapat disimpulkan bahwa tidak terdapat autokorelasi. Uji heteroskedastisitas bertujuan untuk menguji terjadinya ketidaksamaan varian dari residual suatu pengamatan ke pengamatan yang lain pada model regresi, dengan menggunakan model Geljser. Hasil uji heteroskedastisitas yang dilakukan diperoleh nilai signifikansi dari variabel pertumbuhan ekonomi yang sebesar 0,849 nilai signifikansi variabel jumlah angkatan kerja sebesar 0,724 dan nilai signifikansi variabel tingkat upah sebesar 0,651. Nilai tersebut lebih besar dari 0,05 yang berarti tidak terdapat pengaruh antara variabel bebas terhadap absolute residual. Dengan demikian, model yang dibuat tidak mengandung gejala heteroskedastisitas.

Pengaruh Perumbuhan Ekonomi, Jumlah Angkatan Kerja, dan Tingkat Upah Terhadap Penyerapan Tenaga Provinsi Bali, 
Hasil uji $\mathrm{F}$ menunjukkan bahwa nilai signifikansi $\mathrm{P}$ value 0,036 pada hasil analisis regresi memiliki nilai yang lebih kecil dari $\alpha=0,050$ dan $\mathrm{F}_{\text {hitung }}$ sebesar 2,972 $>\mathrm{F}_{0.05}(3: 86)=2,71$, ini berarti model yang digunakan pada penelitian ini adalah layak. Hasil ini memberikan makna bahwa pertumbuhan ekonomi, jumlah angkatan kerja, dan tingkat upah secara simultan berpengaruh sigifikan terhadap penyerapan tenaga kerja pada Kabupaten/Kota Provinsi Bali. Hasil ini didukung oleh nilai koefisiensi determinasi $\left(\mathrm{R}^{2}\right)$ sebesar 0,328 atau 32,8 persen yang artinya bahwa sebanyak 32,8 persen variasi dari penyerapan tenaga kerja Kabupaten/Kota Provinsi Bali dijelaskan oleh pertumbuhan ekonomi, jumlah angkatan kerja dan tingkat upah, sedangkan 67,2 persen sisanya dijelaskan oleh faktor lain yang tidak dijelaskan dalam model.

Berdasarkan hasil analisis regresi mengenai pengaruh variabel pertumbuhan ekonomi diperoleh nilai signifikan 0,514 dan thitung 0,655 dimana $t_{\text {hitung }}=0,655<\mathrm{t}_{0,05: 86}=1,663$; dengan tingkat signifikansi 0,514 >0,050 mengidentifikasikan bahwa pertumbuhan ekonomi secara parsial tidak berpengaruh terhadap peyerapan tenaga kerja di Kabupaten/Kota Provinsi Bali. Setiap peningkatan 1 persen pada pertumbuhan ekonomi, tidak berpengaruh terhadap bertambah atau berkurangnya jumlah penyerapan tenaga kerja. Pertumbuhan ekonomi yang tinggi belum tentu dapat menambah penyerapan tenaga kerja. Tidak signifikannya variabel pertumbuhan ekonomi mencerminkan bahwa naik-turunnya jumlah penyerapan tenaga kerja tidak selalu tergantung pada pertumbuhan ekonomi pada Kabupaten/Kota Provinsi Bali 2010-2019. Teori Arthus Lewis pada dasarnya membahas proses pembangunan ekonomi yang terjadi di daerah pedesaan dan daerah perkotaan (urban). Dalam teorinya, Lewis mengasumsikan bahwa perekonomian suatu negara pada dasarnya terbagi menjadi dua, yaitu perekonomian tradisional di pedesaan yang didominasi oleh sektor pertanian dan perekonomian modern diperkotaan dengan industri sebagai sektor utama. Di pedesaan, karena pertumbuhan penduduknya tinggi, maka terjadi kelebihan suplai tenaga kerja dan tingkat hidup masyarakatnya berada pada kondisi subsisten akibat perekonomian yang sifatnya juga subsisten. Over supply tenaga kerja ini ditandai dengan nilai produk marjinalnya nol dan tingkat upah riil yang rendah. Kerangka pemikiran teori Chenery pada dasarnya sama dengan model Lewis. Teori Chenery, dikenal dengan teori pattern of development, memfokuskan pada perubahan struktur dalam tahapan proses perubahan ekonomi di LDCs yang mengalami transformasi dari pertanian tradisional (subsisten) ke sektor industri sebagai mesin utama pertumbuhan ekonomi.

Hasil penelitian ini didukung oleh penelitian yang dilakukan oleh Sokian (2020), Ambar \& Indrajaya (2019), Yulia Pangastuti (2015), Nur Insana (2019) yang menyatakan bahwa pertumbuhan ekonomi tidak berpengaruh signifikan terhadap variabel terikat penyerapan tenaga kerja. Hal ini disebabkan tenaga kerja di Kabupaten/Kota Provinsi Bali tidak semua berasal dari daerah itu sendiri, melainkan dari luar daerah. Faktor migrasi dapat mengakibatkan naiknya pertumbuhan ekonomi apabila migran yang masuk kedalam suatu daerah merupakan angkatan kerja yang tingkat produktifitasnya tinggi. Dengan tingkat produktivitas yang tingga maka migran yang masuk dapat membantu daerah tujuan dalam mengolah sumber daya yang dimiliki sehingga pendapatan daerah tersebut akan maksimal. Namun sebaliknya, apabila migran yang masuk bukan angkatan kerja, maka akan menambah jumlah pendududk yang tidak produktif. Sehingga menjadi beban bagi perekonomian daerah tersebut serta akan memperlambat terjadinya pertumbuhan ekonomi.

Berdasarkan hasil analisis regresi mengenai pengaruh variabel jumlah angkatan kerja diperoleh nilai signifikan sebesar 0,027 dan thitung 2,250 dimana $t_{\text {hitung }}=2,250>\mathrm{t}_{0,05: 86}=1,663$; dengan tingkat signifikansi 0,027 $<0,050$ mengidentifikasikan bahwa jumlah angkatan kerja secara parsial berpengaruh positif dan signifikan terhadap penyerapan tenaga kerja di Kabupaten/Kota Provinsi Bali.

Pengaruh Perumbuhan Ekonomi, Jumlah Angkatan Kerja, dan Tingkat Upah Terhadap Penyerapan Tenaga 
Jika angkatan kerja naik sebesar 1 orang, maka jumlah penyerapan tenaga kerja naik sebesar 4,730 persen dengan asumsi variabel lain konstan pada tingkat signifikansi 5 persen atau 0,05. Semakin tinggi jumlah angkatan kerja, maka jumlah penyerapan tenaga kerja akan naik. Hasil penelitian ini sesuai dengan teori Lewis yang menyatakan bahwa angkatan kerja berpengaruh terhadap penyerapan tenaga kerja. Bahwa kelebihan tenaga kerja merupakan kesempatan dan bukan menjadi hambatan, karena kelebihan pekerja pada satu sektor akan berperan dalam penyediaan pekerjaan di sektor lain (Mulyadi, 2008).

Hasil ini diperkuat dengan hasil penelitian yang dilakukan oleh Tirani (2016), Rakhmawati \& Arfida (2018) juga menyatakan bahwa angkatan kerja berpengaruh positif terhadap penyerapan tenaga kerja. Jadi semakin tinggi jumlah angkatan kerja maka akan semakin banyak tenaga kerja yang bekerja dengan tersedianya lapangan kerja. Karena dengan usia produkstif akan lebih membantu produksi barang atau jasa.

Berdasarkan hasil analisis regresi mengenai pengaruh variabel tingkat upah diperoleh nilai signifikansi sebsar 0,021 dan $t_{\text {hitung }} 2,357$ dimana $t_{\text {hitung }}=2,357>t_{0,05: 86}=1,663$; dengan tingkat signifikansi 0,021 $<0,050$ mengidentifikasikan bahwa tingkat upah secara parsial berpengaruh positif dan signifikan terhadap penyerapan tenaga kerja di Kabupaten/Kota Provinsi Bali. Apabila tingkat upah naik sebesar 1 rupiah, maka penyerapan tenaga kerja naik sebesar 1,005 persen dengan asumsi variabel lain konstan pada tingkat signifikansi 5 persen atau 0,05 . Semakin tinggi tingkat upah yang diberlakukan maka penyerapan tenaga kerja akan naik.

Hasil penelitian ini sesuai dengan hasil penelitian yang dilakukan oleh Agnes \& Wita (2017) bahwa tingkat upah berpengaruh positif dan signifikan terhadap penyerapan tenaga kerja. Hal ini karena besarnya jumlah orang yang bekerja dipengaruhi oleh faktor kekuatan penyediaan dan permintaan tenaga kerja dipengaruhi oleh tingkat upah. Hal ini karena saat tingkat upah meningkat, maka penyerapan tenaga kerja akan meningkat. Dengan demikian tingkat upah mempunyai hubungan searah terhadap penyerapan tenaga kerja. Kenaikkan upah berarti menaikkan kemakmuran masyarakat.

\section{SIMPULAN DAN SARAN}

Berdasarkan hasil analisis dan pembahasan yang telah diuraikan sebelumnya, maka dapat ditarik kesimpulan bahwa pertumbuhan ekonomi, jumlah angkatan kerja, dan tingkat upah secara simultan berpengaruh signifikan terhadap penyerapan tenaga kerja di Kabupaten/Kota provinsi Bali. Secara parsial, pertumbuhan ekonomi tidak berpengaruh terhadap penyerapan tenaga kerja di Kabupaten/Kota Provinsi Bali, sedangkan angkatan kerja dan tingkat upah berpengaruh positif dan signifikan terhadap penyerapan tenaga kerja di Kabupaten/Kota Provinsi Bali

Berdasarkan hasil penelitian dan simpulan di atas, maka dapat diajukan saran pada aspek tenaga kerja pemerintah diharapkan lebih memfokuskan pada peningkatan kualitas masyarakat terutama pada penduduk usia kerja dengan memberikan layanan pendidikan dan program peningkatan soft skill dan hard skill yang tentunya akan meningkatkan produktivitas tenaga kerja sehingga dapat mempermudah angkatan kerja dalam memperoleh suatu pekerjaan yang sesuai dengan bidangnya masing-masing. Pada kebijakan penetapan tingkat upah, pemerintah diharapkan dapat meningkatkan tingkat upah minimum sesuai dengan kebutuhan hidup masyarakat serta dapat mempertahankan kebijakan upah minimum agar dapat memberikan keadilan bagi pekerja dalam pemberian upah yang layak dan sesuai kebijakan. Pertumbuhan ekonomi yang menghasilkan jumlah output yang besar seharusnya dapat mengambil peran tenaga kerja selama proses produksi berlangsung sehingga

Pengaruh Perumbuhan Ekonomi, Jumlah Angkatan Kerja, dan Tingkat Upah Terhadap Penyerapan Tenaga 
semakin besar jumlah output yang dihasilkan maka semakin besar jumlah tenaga kerja yang diperlukan dalam mengasilkan output tersebut. Pemerintah diharapkan mengupayakan agar pertumbuhan ekonomi yang tinggi nantinya dapat memberikan peluang kerja bagi para pelaku kerja melalui pemberdayaan industri kecil menengah sehingga meningkatkan kesejahteraan masyarakat. Peneliti selanjutnya diharapkan agar dapat mengembangkan lagi hasil penelitian ini dengan menambah atau melihat faktor-faktor lain seperti migrasi masuk yang dapat mempengaruhi penyerapan tenaga kerja di Kabupaten/Kota Provinsi Bali.

\section{REFERENSI}

Agnes Febria na dan Wita. 2017. Analisis Penga ruh Modal, Tingkat Upah dan Teknologi Terhadap Pen yera pan Tenaga Kerja Serta Produksi Pa da Industri Kerajinan Batako. E-JurnalEP Unud, 6(3) 387-413.

Alghofari, Farid. 2009. Ana lisis Tingkat Pengangguran di Indonesia Tahun 1980-2007. Ju rnal Ilmiah Teknik Industri 6 (1), 9-17.

Arsya d, Lincolin. (2016). Ekonomi Pembangunan Edisi 5. Yogy akarta: UPP STIM YKPN

Ashcroft, Vincent \& David Cavanough. 2008. Survey of Recent Development. Bulletin of Indonesian Studies (BIES), 44 (3), 335-363

Askenazy, Philippe. (2003). Minimum Wage, Export, and Growt. European Economic Review 47 (2003), 114 167

Dayuh Rimbawan, Nyoman. 2012. PertumbuhanEkonomi Terhadap Kesempatan Kerja (Ka sus Provinsi B a li 2001-2011), Jurnal PIRAMIDA,8(2), 76 - 84.

Eka Fitri, Rahayu. 2019. Analisis Pengaruh TPAK, Investasi dan UMR Terhadap Penyerapan Tenaga Kerja Pada Seluruh Provinsi di Indonesia. Skripsi. Ekonomi dan Bisnis Universitas Udayana

Kuncoro dan Suhardjono, 2002. Manajemen Perbankan (Teori dan Aplikasi), Edisi Perta ma, Pen erbit B PFE, Yogyakarta.

Mankiw, N. G. (2000). Teori Makroekonomi Edisi Empat. Jakarta: Erlangga

Mulyadi S. (2008). Ekonomi Sumber Daya Manusia dalam PerspektifPembangunan. Jakarta: Rajawali Pers

Nasution, Ahmadriswan. 2015. The Role of Social Capital on Rural Household Poverty Reduction in Indonesia . Bulletin of Indonesian Economic Studies (BIES), 46(6), 122-140.

Neumark, David, and William Wascher. 2007. Minimum Wages and Employment. Journal of Foundations and Trends in Microeconomics 3(1-2), 1-182.

Rakhmawati, Atifatur \& Arfida. 2018. Analisis TingkatPenyerapan Tenaga Kerja Sektor Industri di Kabu paten Gresik. Jurnal Ilmu Ekonomi. 2 (1),74-82.

Sri Budhi, Made Kembar. 2008 "Mengelola Sumber Daya Manusia Dalam Menyongsong Millenium Development Goals (Mdgs). Journal Article. Jurnal Ekonomi da n Sosial, 2(3), 67-83.

Subri. 2003. Ekonomi Sumber Daya Manusia. Jakarta: PT. RajaGrafindo Persada

Tirani, Baiq Kusuma. 2016. Ana lisis Faktor-Faktor yang Mempengaruhi Permintaan Tenaga Kerja di Indone sia Tahun 2006-2013. Jurnal Fakultas Ekonomi Universitas Islam Indonesia Yogyakarta

Vivi Alata s, Lisa Cameron. 2016. The Impact of Minimum Wages on Employment in a LowI ncome Country: An Evaluation using theDifference-in-Differences Approach. International Journal of Economics Universityof Melbourne. 4(3), 1-43. 